\title{
Transatlantic Security Relations Since the European Security Strategy: What Role for the EU in Its Pursuit of Strategic Autonomy?
}

\author{
Michael E. Smith \\ University of Aberdeen \\ June 2018
}

Forthcoming in the Journal of European Integration

Transatlantic security cooperation entered a new era after the 9/11 attacks in America, the launch of EU crisis management/security assistance operations, and the release of the European Security Strategy (ESS) in 2003. Since then, years of practical experience have inspired the EU to enhance its ambitions in this realm by developing a Cybersecurity Strategy, a Maritime Security Strategy, and most recently, the 2016 EU Global Strategy (EUGS). As these efforts respect NATO's primary role in European defence, there is more scope for practical EU-US collaboration regarding crisis management and security assistance. However, although there have been some clear successes here, the EU is also increasingly willing to forge its own path in this realm and possibly diverge with US priorities. This article evaluates the recent record of, and prospects for, EU-US security collaboration regarding various problems mentioned as strategic priorities in the ESS, EUGS, and related documents.

I would like to acknowledge the support of the European Research Council (grant \#203613) for funding the research drawn upon in this article. I am also grateful to the editors of this special issue and to the anonymous referees of the Journal of European Integration for their comments on an earlier draft. Finally, I would like to thank the European University Institute for the award of a Robert Schuman Fellowship, which provided a very congenial atmosphere to complete this article. 
The post-Cold War era has been characterized by a dramatic expansion of the international security agenda to include a range of new security challenges well beyond those associated with interstate warfare. Many of these problems, which often arise as individual crises, have put great stress on the transatlantic security relationship, one of the most important partnerships in modern world politics. Although Americans and Europeans may agree on the general need to manage many of these issues, the two sides have also exhibited considerable divergence regarding the appropriate response in specific cases; this tendency can be seen in other critical areas as well, such as financial market regulation after the 2008 global economic crisis (Pagliari 2013). America's 'war on terror' and its armed interventions in Afghanistan and Iraq have been particularly contentious, yet the strains on transatlantic security relations extend to other problems: reforming fragile states; responding to refugee or other humanitarian crises; the militarization of the fight against drug trafficking and organized crime; the use of private military contractors; ongoing debates over nuclear deterrence, arms control, and disarmament; the use of drone strikes; the security of cyberspace (including privacy issues); and so on.

To what extent, then, is the transatlantic security relationship converging or diverging in light of current political trends on both sides of the Atlantic? And what are the prospects for effective transatlantic cooperation in the face of these new security challenges? This article addresses these questions, focusing on whether the US and the EU can manage to cooperate in light of the apparently never-ending pressures of various crises. Specifically, I argue that the contending explanations drawn from realism (calculations about power and threats), liberalism (Europe's regional challenges and institutional development), and social constructivism (Europe's unique history, identity, and shared values) are inadequate on their own to 
explain the practice of transatlantic security cooperation. ${ }^{1}$ Nor is it possible to label the transatlantic security relationship in very general terms (i.e., an emerging EU superpower, unravelling transatlantic relations, US hegemony, or differentiated relations ${ }^{2}$ ), as it varies considerably depending on the specific problem at hand. Even during the difficult years of the first George W. Bush presidential term and the intensive intra-EU disputes over the Iraq War, for example, the US and the EU still managed to pursue effective cooperation on a number of fronts. Similarly, when the EU itself is unified it is not accurate to characterise its security actions in terms of a 'superpower' (when transatlantic relations are strained) or to frame America's role in terms of 'hegemony' (when transatlantic relations are strong).

In this article, I engage with these ideas, which are individually indeterminate in exploring the questions posed earlier, by linking them to the EU's actual practice within this realm, and thereby attempt to build upon studies that focus on the rhetoric or discourse used by the EU to justify its security policies through the use of public statements or doctrines ranging from the 2003 European Security Strategy (ESS) to the 2016 EU Global Strategy (EUGS). In fact, one major analytical puzzle in examining EU security policy is the very wide gap that persists between the EU's stated ambitions and its actual achievements in this realm. Thus, the main focus here is on how EU security practices have changed in ways that will continue to complicate the US-European security relationship despite the best efforts of any US presidential administration to maintain European support for American policies.

In the sections that follow, I first argue that the EU's emergence as an international security actor has been driven as much, if not more, by the EU's need to respond to specific challenges (crises and otherwise) on its borders as it is by a general European strategic doctrine that can be traced to any single theoretical causal 
logic, whether based on realism, liberalism, or constructivism. In the second section, I focus more specifically on two key areas of US-EU divergence in this realm: multilateralism and the use of military force, topics where the EU has been attempting to forge its own path in international security affairs rather than reflexively following America's lead. In the third section, I examine the recent practice of US-EU security relations, which does show evidence of cooperation despite a larger pattern of divergence extending back many years. In the fourth and final section, I argue that although some degree of transatlantic cooperation is likely to persist in areas of common interest, it seems the trend of divergence is likely to persist in light of the EUGS, Brexit, the election of Donald Trump, and other developments.

\section{From theory to practice: The EU becomes a security actor}

Although transatlantic disagreements about security cooperation were evident even during the Cold War, ${ }^{3}$ the collapse of the Soviet Union and the demise of the Warsaw Treaty Organisation put new pressures on the US-EU relationship. Debates about their shared commitment to security that used to be somewhat ad hoc and even somewhat theoretical now became more critical and tangible, as NATO had to consider whether to re-invent itself or go out of business, while the Europeans were forced to consider a future without an American security guarantee. A great deal of political and conceptual energy was focused on these questions through the 1990s, and the result by the end of that decade was a kind of strategic bargain between the two sides. This involved the maintenance of NATO for transatlantic defence affairs, with attention to new types of missions (such as counterterrorism and cyber-security), as well as America's acceptance of an independent EU security capability - through its Common Security and Defence Policy (CSDP) - that could supplement, but not 
fundamentally replace or duplicate, NATO. This European capability progressed in stages since then and was intended primarily to cope with security challenges similar to those generated by the violent collapse of Yugoslavia: the so-called 'Petersberg Tasks. ${ }^{4}$ Between 2000 and 2004, a wide range of CSDP support institutions, both military and civilian, were created within the EU, while formal arrangements for EUNATO military cooperation were established after six years of contentious talks (the 'Berlin Plus' agreement ${ }^{5}$ ). Finally, the EU also instigated a de facto "absorption" of the Western European Union and its limited institutional infrastructure.

These achievements regarding the maintenance of the NATO-EU relationship still masked an uncomfortable truth for the EU: its apparent unwillingness to launch its own independent security operations. A number of scholars - mostly but not exclusively associated with realism - continued to note two basic EU problems: a reluctance to devote more resources to military power and an inability to devise institutional procedures to use various resources in a credible and effective manner (Glaser 1993; Art 1996; Gordon 1997-98; Hoffman 2000; Kagan 2003). These problems were then used to justify, or at least explain, the continued dominance of the US in transatlantic security affairs: even if the EU could manage to address the two problems above, it still could not hope to compete with, or act credibly in opposition to, American leadership if their views on security diverged. Thus the practical division of labor between the US/NATO and the EU was still primarily a theoretical question. The EU was almost painfully aware of its limitations, especially after NATO's armed intervention in Kosovo/Serbia, and attempted in 2003 to bridge the gap between theory and practice by advancing its own views regarding European security. 
The result was the EU's first-ever European Security Strategy (ESS) in December 2003 (Solana 2003). ${ }^{6}$ This paper identified five major threats to European security (terrorism, weapons proliferation, regional conflict, state failure, and organized crime); emphasized that European security must first be enhanced in its own neighbourhood by stabilizing the Balkans and extending cooperation and security to the east and south; and articulated the principle of 'effective multilateralism' as a cornerstone of EU foreign policy. These priorities clearly challenged the US approach under the G.W. Bush administration, especially regarding the stress on multilateralism and the focus on root causes (i.e., state weakness or failure) of other problems. ${ }^{7}$ Moreover, these efforts regarding external security were increasingly linked to internal EU security policies, particularly those involving Justice and Home Affairs matters. ${ }^{8}$

The most dramatic change in the context of the ESS, however, was the EU's decision to lead its own security operations under the rubric of the CSDP. Since 2003, the EU has made use of this tool by initiating over 30 CSDP operations and related actions in support of them; in addition to numerous civilian CSDP missions, these have also involved the deployment of land-based military forces in the Balkans and Africa as well as the launch of maritime security operations off the Horn of Africa and in the Mediterranean. These operations will be discussed in more detail below; the critical point here is that these new EU operations, and their congruity with various related efforts in internal EU security affairs and development/humanitarian aid policy (Mounier 2009; Cross 2017), demonstrate that the transatlantic debate about security is no longer theoretical or rhetorical: as CSDP operations expanded in scope and complexity, the Europeans were increasingly forced to justify themselves not in terms of principled but largely passive opposition to some American policies, 
but in terms of their own leadership, effectiveness, values, and capacity for innovation and risk-taking regarding similar efforts.

Moreover, these changes cannot easily be explained by general theories of security cooperation, such as those involving balancing against power or threats. As the CSDP does not take the form of an EU alliance and/or army, and has not led to a major increase in European defence spending or military capabilities, it does not represent 'hard balancing' as some (Posen 2006) have argued. Similarly, other analysts suggested that the Europeans were now 'soft balancing' against not the general fact of American military primacy, but against the specific policies of US presidential administrations, particularly their resort to unilateralism and their use of preventative and/or excessive military action, such as the 2003 invasion of Iraq (Pape 2005; Paul 2005). In this view, the Europeans are merely reacting to the aggressive policies of American presidents, rather than devising their own novel and independent views regarding a European contribution to security affairs for reasons that might be completely unrelated to the question of American power. Balance against threat theory (Walt 1987) also lacks analytical weight, as the vast majority of CSDP actions do involve direct or indirect threats to European security; they are largely policies of choice, not necessity (Smith 2017).

Even if exogenous factors like US power, fears of American abandonment, or regional security threats play some role in the general trend toward more EU security actions since 2003, it also seems clear that endogenous European factors explain how the EU specifically chooses when and how to act. Liberal theories for example, particularly those regarding the role of interdependence and international institutions, suggest that shared problems and shared vulnerabilities - and not just in security affairs - help to create a demand for common European policies, while periodic 
institutional innovations in the form of various EU organizations and policy tools (such as the CSDP) help to supply those common policies for the benefit of all EU member states (Regelsberger, de Schoutheete de Tervarent, and Wessels 1997; Winn and Lord 2001; Smith 2003). Similarly, social constructivist arguments, which often incorporate or build upon liberal views, interpret the EU as a source of new ideas, norms, and methods for promoting security and global governance based on its own multilateral and highly institutionalized identity. Some scholars also stress the EU's desire to re-fashion world politics in its own image: as a cosmopolitan, multilateral, post-Westphalian, post-modern/post-materialist pax Europa with growing global influence (Whitman 1998; Leonard 2006; Magone 2006; McCormick 2006; Whitman 2011) and its own nascent strategic culture (Cornish and Edwards 2001; Meyer 2005). The critical point, however, is that despite its enhanced efforts since the late 1990s, the EU is still very selective when it considers whether to devise a common policy in response to a particular security problem. Moreover, none of the general theories discussed above are very helpful, on their own, in explaining exactly when and how the EU chooses to act. Therefore they are also limited in predicting the extent to which American and European policies in security affairs are likely to converge or diverge. To understand why, we need to examine closely the EU's actual behaviour as a security actor, and not just in terms of discourse, rhetoric, or strategic statements like the 2003 ESS or the 2016 EUGS. We also need to undertake a kind of net assessment of instances where the US and EU cooperated and where they disagreed regarding certain international security problems to determine whether these patterns really represent divergence or convergence, at least on this topic. Before doing so, however, it is necessary to review how the US and the EU have 
diverged for years regarding two central issues in international security affairs: multilateralism and military force.

\section{Multilateralism and military force in transatlantic security affairs}

European discomfort at being viewed as a junior partner to the US in world politics during and after the Cold War clearly inspired more general European foreign policy cooperation, in the form of European Political Cooperation (EPC) in the 1970s, and the emergence of the Common Foreign and Security Policy (CFSP) and, later, the CSDP, in the 1990s (Nuttall 1992; Smith 2003). However, as noted above this response is neither a specific reaction to American hegemonic power alone, nor is it traceable to perceptions of the US as a threatening force. Nor have EU member states in NATO abandoned the idea of a common defense pact, in the form of NATO's Article 5 guarantee, even as they increasingly attempt to develop their own intra-EU defence cooperation (i.e., the emerging 'European Defence Union'9 ${ }^{9}$. Instead, the EU's approach to international security, as framed by its own top decisionmakers, involves a utilitarian ethic in terms of what policies it believes are most effective in the management of Europe's modern security problems; and a deontological ethic in terms of what policies it believes are not just more effective but also more reflective of the fundamental values of a larger community, in this case the EU itself.

These dimensions, which can also be framed as a 'functional logic' and a 'logic of appropriateness' (March and Olsen 1989), are also directly related: greater effectiveness can improve perceptions of legitimacy. This two-dimensional ethics debate also involves both an external and internal component: EU external policies, and the values they reflect, must be justified both to the outside world and to other members of the community on whose behalf the policies are being made, in this case 
the EU as an institution with its own discursive and international legal identity rather than as just a club or common market or loose grouping of states, as in an alliance. ${ }^{10}$ As the existence of the EU itself is inherently dependent on increasingly institutionalized multilateral cooperation, the rule of law, and a preference for the peaceful resolution of disputes whenever possible, it only makes sense that it would attempt to promote and defend that approach - and thus its own legitimacy - when it attempts to engage with outside actors about specific issues. In addition, as we shall see in the next section, although the EU does have recourse to military force, such actions actually represent only a small portion of its external security activities, so that the EU still largely remains a 'civilian power' in world politics despite the advent of the CSDP (Orbie 2006; Telò 2006); this further undermines the balancing-againstAmerica hypothesis of EU security/defence cooperation.

These factors, in turn, suggest that despite its willingness to cooperate with America, the EU does represent itself as a security actor in ways that are fundamentally different than the US, and has done so long before the election of Donald Trump. Specifically, when compared to the EU's rhetoric and actions, America is far more willing and able to: 1) act unilaterally to secure its interests; 2) use force without the approval of the UN Security Council; 3) consider not just preemptive but also preventive action against potential threats; 4) use a full range of military resources, including covert actions, drone strikes, and the threat of nuclear weapons; and 5) deploy force globally for a wide range of purposes well beyond mere homeland defense or security: deterrence (both direct and extended), compellence, offensive war-fighting, signaling, punishment, rescue missions, humanitarian aid, and so on. In short, then, the US feels relatively unconstrained in its approach to the use of military force, and it highly unlikely to accept any such constraints - whether in 
terms of legal restrictions, human rights concerns, arms control norms, or the views of its allies - when it feels its security is threatened.

The EU, on the other hand, claims and attempts to act only within various constraints even while hoping to improve both its effectiveness and its legitimacy as an international security actor. First, the EU clearly does not give primacy to military force and it stresses the virtues of a full range of power resources, including economic power (i.e., market access and financial aid, as well as sanctions), non-material forms of power (i.e., 'soft', 'civilian', 'ethical' or 'normative'), ${ }^{11}$ less-threatening types of armed force in the form of police, constabulary, or gendarmerie forces, and the principled and strategic co-mingling of all these forms of power in specific cases, which is now known as the EU's 'comprehensive' or 'integrated' approach to foreign/security policy (Smith 2013; Major and Mölling 2013). Second, it recognizes the limits of offensive military power in handling complex security problems (beyond strict territorial defense), as well as the fact that military operations might make matters worse for those who exercise it (i.e., reduce one's security) by increasing local resistance in the target country through insurgencies or similar tactics (Lucarelli and Menotti 2006). Third, as the EU now has recourse to military resources, as a last resort, to defend its values and principles, it is also actively working to integrate this new capability into its broader integration project through institutional reforms (the CSDP), resource re-allocation (the European Defence Agency, a European Defence Fund, Permanent Structured Cooperation regarding defence capabilities, and others), common strategic plans (the ESS and the EUGS), sector-specific policies (maritime security and cyber-security), and other policy initiatives.

Overall, then, the EU's self-stated approach to security is supposed to be a mirror reflection of the intense, highly institutionalized, multidimensional, and 
multilateral cooperation that occurs among EU member states themselves. Based on this conception of the EU's role, the most important general predictors of US-EU tension over questions of international security involve the role of multilateralism, of military power as a last resort (if at all), and of the rule of international law (mainly the UN system): every element of EU strategy and policy attempts to respect these principles as foundational or core European values, while the US is willing to support or abandon multilateralism, the rule of law, and the views of the UN as it sees fit, as well as resort to armed force sooner rather than later. As a 'first cut' at predicting divergence, then, it seems that the EU's support of or opposition to US security policies would be critically dependent on America's own willingness to deploy force and its broader commitment to multilateralism, the UN, and international law, which was already fragile long before Trump's election when America invaded Iraq in 2003.

\section{Transatlantic relations and the practice of European security cooperation}

These factors suggest continued divergence, and possibly transatlantic discord, regarding international security affairs broadly defined, with two important caveats to bear in mind: First, the EU's limited ability to act decisively and independently in the face of serious problems when other actors (such as Russia or the US) are not supportive; and second, the ongoing willingness of the US and the EU to cooperate effectively when they have shared interests, which means that any further divergence we do see in transatlantic security affairs in coming years will not necessarily paralyze transatlantic relations in a permanent fashion.

Regarding the first caveat, it is clear that the EU has not always demonstrated a high degree of internal unity regarding important international security problems, such as those stemming from the Arab Spring revolutions. As EU itself is a treaty- 
based international organisation, and as its member states still vary widely in terms of their commitments to various forms of security/defence cooperation (through the EU, NATO, and other arrangements, including neutrality ${ }^{12}$ ), it is still most appropriate to see the EU not so much as an international security provider/actor but rather as an evolving pluralistic security community (Deutsch et al. 1957), which is based on shared values, sensitivity to each other's needs, communication, trust, predictable behavior, and support for international law and institutions (chiefly through the UN system). This general approach to security community-building is supported by various specific confidence-building mechanisms among EU member states, such as the CFSP and the new European External Action Service, to facilitate common viewpoints and lay the groundwork for joint action in security affairs through the CSDP and related policies.

This view of the EU as a security community bound by shared values and institutions, rather than as a loose organisation or alliance of independent states buffeted by world politics, also dovetails with the EU's desire to play a greater role in global affairs in accordance with its identity and values (Linklater 2005; Lucarelli and Manners 2006; Bailes 2008). Particularly since its internal discord over the 2003 Iraq War, which inspired the release of the ESS later that year, the EU increasingly wants to prove itself as a capable global political actor, both to its own citizens and to outside actors, whether allies or threats or potential members/partners. However, it is still painfully obvious that the EU has not always lived up to its claims as a security provider in areas where it claims to have a major interest, such as the Middle East, North Africa, and the eastern borders of the EU itself. In some cases the EU failed to act at all; in others the EU took too long to act to make a real difference; and in others the EU did act quickly but was not resourced adequately and/or had to scale back its 
mandate because of factors beyond its control, whether inside or outside of the host country. ${ }^{13}$

Regarding the second caveat, it is quite clear that there have been several examples of positive US-EU security cooperation in areas of shared interests when taking a closer look at the range of CSDP actions in recent years. This tendency extends back to the launch of the first CSDP operations in 2003, two of which (Concordia and Althea) involved take-overs of NATO military peacekeeping operations in the Balkans and which required, therefore, extensive discussions between the US and the EU. These were also the first test cases of the Berlin Plus arrangement for the EU's use of NATO assets, and helped to facilitate American deployments elsewhere (which also undermines the 'soft balancing' against the US thesis)(S. Smith 2013). Beyond military peacekeeping, a second area of opportunity can be seen in the realm of counter-piracy operations, whereby the EU and NATO, again, coordinated their efforts in mounting various naval patrols and a safe transit corridor in the Gulf of Aden region off the Horn of Africa after 2008; this cooperation (coordinated by EUNAVFOR Somalia) also extended to NATO's handover to the EU of suspected pirates for transport to countries where they could be tried for their crimes (Germond and Smith 2009).

A third major example involves the EU's supporting role in providing police training and other assistance after the launch of the American-led wars in Afghanistan (2001) and Iraq (2003). These efforts (EUPOL Afghanistan and EUJUST-LEX Iraq) put enormous strains on the EU, especially as the CSDP was barely up and running when they were launched, yet the EU persisted with them to demonstrate its unity and to support US policies (Korski 2009; Kempin and Steinicke 2009). A fourth example involves the EU's growing cooperation with NATO in the realm of cybersecurity and 
hybrid warfare, particularly through NATO's new cybersecurity facility in Estonia as well as a European Centre of Excellence for Countering Hybrid Threats in Finland. Cybersecurity clearly is a problem that transcends the EU's geographical space and therefore requires extensive and ongoing cooperation among actors with shared interests and vulnerabilities, so it is vital that the EU and NATO develop these joint capabilities (Sliwinski 2014).

A fifth and final major example involves EU and NATO cooperation in responding to the refugee crisis in the Mediterranean, through joint naval operations (coordinated by EUNAVFOR Med). And beyond these specific CSDP actions that benefit transatlantic security concerns, the US and the EU have also worked together in other areas of common interest, such as negotiating restrictions on Iran's nuclear programme and maintaining a sanctions regime against Russia for its annexation of Ukraine. ${ }^{14}$ This overall pattern clearly indicates that the US and the EU will remain open to joint action in security affairs when they perceive a common challenge, even as the US continues to criticise European NATO member states for not spending more on defence. However, the much broader and longer-term trend (well before the Trump administration) seems to suggest a greater degree of EU independence in international security affairs, thanks not only to the 'America first' attitude that Trump represents but also to the UK's pending exit from the EU and, perhaps more importantly, the ongoing regional security problems facing the EU.

\section{Prospects: The 2016 EUGS and beyond}

Specifically, the EU's adoption of the 2016 EUGS and its related security policy commitments since then make it clear that the EU does intend to enhance its capabilities in order to guard against security problems that are not viewed as 
priorities by the US. It is also clear that the EU will take such actions even when it may violate certain understandings or expectations on the part of US policymakers. For example, the EU did not even inform the US when it launched its first independent CSDP peacekeeping operation in the Democratic Republic of the Congo (Artemis). This act defied America's preference to allow NATO (i.e., the US) to vet all CSDP military operations, even those that did not require access to NATO assets (Ulriksen, Gourlay, and Mace 2004). The US, often supported by the UK, also opposed the EU's creation of its own small operational headquarters (OHQ) in Brussels for CSDP operations, which was achieved finally in early $2007,{ }^{15}$ while for its part the EU shunned any further use of the Berlin Plus mechanism, which required intensive talks with the US to develop during the two test cases above (Concordia and Althea), because it was too easy for other NATO members to block, delay, or otherwise influence the EU's borrowing of NATO assets. Since Althea, there have been no uses of Berlin Plus at all, although the EU and NATO have enhanced their cooperation in other areas under the 2016 Warsaw Declaration.

Even before the advent of the Trump administration, which put new strains on the US-EU security partnership, the EU was already developing more detailed security plans that may or may not mesh with American priorities. As noted above, the 2003 ESS identified five key threats; in 2008, a review process in the EU added two new problems - energy security and climate change - while also mentioning cyber-security. ${ }^{16}$ Although the US and EU are working together on cyber-security as noted above, climate change in particular will be an area of ongoing tension, as long as US Republican administration officials from Trump downwards continue to reject scientific findings on the link between human activity and global warming. 
The 2016 EUGS broadens EU strategic thinking even further than the more specific security doctrines like the ESS and the Maritime Security Strategy, and upholds the central priority of multilateral cooperation as a tool to develop global governance, which again distinguishes the EU from America's willingness to resort to unilateralism. The EUGS in fact mentions five strategic priorities as follows:

* Security and defence (including a deterrence capability)

* Enhancing state and societal resilience to our East and South

* An integrated approach to conflicts and crises

* Promoting cooperative regional orders

* Enhancing global governance for the 21 st century

These priorities have already appeared, though perhaps in slightly different forms, in other EU planning documents going back to the ESS and earlier, and there is one important theme that links many of them: the notion of strategic autonomy for the EU. The 2033 ESS, for example, mentioned the need to develop a European strategic culture 'that fosters early, rapid, and where necessary, robust intervention,' while the EUGS mentions the goals of strategic autonomy and responsiveness. In other words, EU strategy is not just about taking action; it is about the EU's (potential) freedom to choose among various courses of action, particularly during a crisis, rather than have difficult decisions forced upon it or have other major players, such as the US or Russia, take action. This also involves being more proactive rather than reactive, and then being effective and credible when EU action is taken; these goals have eluded the EU in many ways but it is very clear that the EU recognises this problem and is taking specific steps to address it. Thus, even though full EU strategic autonomy, like the general idea of 'ever closer union,' will remain elusive if defined in strict terms (i.e., as not being constrained by any other actor), it may still allow the EU to become more independent of the US in security affairs but not necessarily regarding territorial deterrence/defence, where NATO still dominates. 
Overall, then, the EU is attempting to combine an already-existing, very wide set of capabilities not available to many other global actors into a unified framework (i.e., the comprehensive or integrated approach) while also reforming its institutional structure to deploy those resources in a more effective manner for specific security problems (i.e., strategic autonomy from the US in particular). These ideas also reinforce the notion of the EU as a 'one stop shop' for various security services, crisis management, and post-conflict support tasks given its range of available policy tools: from civilian/diplomatic to economic to police/judicial to military. All of these efforts, along with other security priorities noted above and more general EU principles (multilateral cooperation through institutions, the rule of law, and support for the UN system), also suggest that the EU may become more willing to forge its own path in security affairs, and possibly diverge from American goals.

The most recent example is Europe's immediate response to Trump's decision to withdraw America from the Joint Comprehensive Plan of Action (JCPOA) regarding Iran's nuclear programme, which inspired solidarity to salvage the JCPOA among not just senior EU officials, Germany, and France but the UK as well, even as it is planning to leave the EU. Although the JCPOA may still collapse, this pursuit of European independence in security more generally could be the case for the foreseeable future even while transatlantic relations seem to be relatively stable (through the EU-NATO linkage) in the realm of territorial defence and related domains, such as cyber-security/hybrid warfare. Moreover, it is also clear that major challenges like Brexit, Russia, and Trump have helped to bring many (though certainly not all) Europeans closer together in support of the EU project, and thereby dampen some of the anti-EU sentiment that seemed to be evident just prior to the EU referendum in the $\mathrm{UK} .{ }^{17}$ 


\section{Conclusion}

After years of debates about the creation of independent European armed forces, the EU has been launching its own CSDP military, policing, and other security operations for over fifteen years. With these actions the EU has deployed a full range of foreign and security policy instruments, some of which did not even exist less than two decades ago. These efforts clearly demonstrate the EU's growing confidence as a security actor, and its ability to back up its aspirational goals with innovative foreign policy operations. Of course, the EU still has major capabilities shortfalls in the areas of mobility, sustainability, logistics, reconnaissance, surveillance, and intelligence. And although the EU has demonstrated that it has the capability to bring together all of its policy instruments, both practitioners and analysts alike suggest far more work is needed to ensure effective use of those combined instruments, and to respond to more violent emergencies if peacekeeping fails. That said, since 2003 CSDP actions have been undertaken in a range of conflict zones and have extended well beyond the EU's own backyard to Africa, the Middle East, and even Asia; this reveals a new capacity for external action that was barely possible in the 1990s.

I have argued that these efforts - which also represent the EU's ability to act more independently of American policies - cannot be explained by major monocausal theories of international relations or European integration, such as realism (balance of power and balance of threat), liberalism (interdependence, institutions, and functional regime theory), and social constructivism (discourse, ideas, and identity). However, certain elements of these theories do provide part of the overall picture. Realists are correct that the US has some influence over debates about European security affairs, but not only by virtue of its power or its potentially 
threatening policies (including abandoning NATO). Instead, the US is also important to the EU for its demonstration effects: America shows Europeans the limits of hegemonic or unilateral approaches in general (such as unilateral withdrawal from the JCPOA), and of aggressive military policies in particular (such as the use of torture or drone killings in the war on terror), regarding the resolution of contemporary international security problems. Liberals are also correct that Europeans are inspired by the importance of multilateral institutional solutions to common security problems often generated by interdependence, yet while this theory can shed light on the creation of institutions such as the CSDP framework, it is less effective in explaining why the EU acts in some areas but not in others. The same holds true for social constructivist theories, which may be useful as post hoc explanations of EU actions but are less effective in terms of their a priori predictive and deductive validity.

Instead, this article has taken a closer look at how the EU attempts to balance these various factors - which are not mutually exclusive - when converting its ideals into actual practice, through a range of specific CSDP missions and the related efforts to fashion a European approach to international security. I have argued that these efforts can be framed as a form of new thinking on the part of the EU regarding the ethics of force: a utilitarian ethic and a deontological ethic. These ethics, which have developed as a result of the EU's growing experience as a security actor, can also be framed in terms of a recognition of Europe's own responsibility in world politics, and the related recognition that some responses to security cooperation can make matters worse. Since the CSDP is not NATO, and thus does not offer a formal defence commitment, its appeal is widened for countries and organizations who desire a European (not American) presence to help stabilize a security situation with only limited (i.e., not offensive) military or police forces. ${ }^{18}$ Failed states and civil wars 
almost always require an outside party to help achieve peace when one side or the other cannot achieve a decisive total victory (Walter 1997; Gent 2008), and the UN and the US are clearly over-stretched regarding these types of missions. ${ }^{19}$

This means, in turn, that the US and the EU may continue to experience transatlantic discord about the role of multilateral security cooperation as an alternative to unilateral policies often favoured by the US. However, based on the transatlantic track record since 2003, this problem is not insurmountable if the US and the EU can agree on a workable division of labour between their respective forces, as seems to be happening since the July 2016 NATO Warsaw Summit - before Trump was elected. That said, both the US and the EU can be accused of failing to respond effectively to certain security problems in recent years, such as the collapse of Libya and Syria (Huber 2015; Noutcheva 2015). For its part, the EU still does not possess its own credible military capability for either deterrence or war-fighting against another major power and, even if it did, it is questionable whether the EU itself would undertake a more punishing operation as NATO did in Serbia/Kosovo to compel or deter a foreign military force. Thus, it is worth considering whether the EU's pursuit of such a capability, even if only on paper, might actually undermine the EU's reputation as a civilian or ethical power and thus violate its own values. Here the US and the EU share one important trait: a disjuncture between their stated ethics and their ethics as they actually live them (Lucarelli and Manners 2006; Stoddard 2015).

This problem deserves more attention in light of the EU's ambitions regarding security and strategy, particularly if these ambitions are framed as distinct from American views. If the CSDP and its various resources are primarily oriented towards foreign interventions rather than deterrence or defense of the EU itself, which seems to be the case, then there is a real risk that the EU will find itself caught in a 
major strategic dilemma: whether to risk innocent civilian lives by attacking the perpetrators of human rights violations (a Kosovo-type dilemma) or whether to offer only token protection to victims and allow them to be slaughtered by a stronger force (a Srebrenica-type dilemma). The EU's reliance on American air power in the Kosovo War was a major impetus behind the CSDP, yet we still do not know the extent to which the EU would use these new forces in a more aggressive or punishing manner to save lives (for example, to stop a genocide), and whether such use would undermine the EU's other normative goals as a civilian or civilizing power. Although the EU has used deadly force under the CSDP to defend its troops and host country civilians against local militias, as in sub-Saharan Africa, it is still worth asking whether the EU might be better off by distancing itself from NATO-type capabilities and military operations rather than by imitating them. This path, however, seems to have been rejected recently in favor of more pro-active global ambitions in the name of strategic autonomy; this trend also suggests that despite fears of an EU collapse since Brexit, the EU still shows many signs of life, and not just in the realm of security. Thus the EU's learning curve as an independent security actor is likely to remain quite steep, and possibly become very painful, as it takes on new challenges. As the saying goes: experience is a hard teacher because she gives the test first and the lesson afterward. ${ }^{20}$ 


\section{References}

Art, R.J. (1996). Why western Europe needs the United States and NATO. Political Science Quarterly 111, no. 1: 1-39.

Bailes, A.J.K. (2008). The EU and a 'better world': what role for the European Security and Defence Policy? International Affairs 84: 115-30.

Brownlee, J. (2007). Can America nation-build? a review essay. World Politics 59: 314-40.

Cornish, P., and G. Edwards (2001). Identifying the development of an EU 'strategic culture.' International Affairs 77, no. 3: 587-604.

Cross, M. (2017). Counter-terrorism in the EU's external relations. Journal of European Integration 39, no. 5: 609-24.

Dannreuther, R., and J. Peterson (eds.)(2006). Security strategy and transatlantic relations. Oxford: Routledge.

Deutsch, K., et al. 1957. Political community in the North Atlantic area. Princeton: Princeton University Press.

Dijkstra, H. (2010). The military operation of the EU in Chad and the Central African Republic: good policy, bad politics. International Peacekeeping 17: 395-407. Engberg, K. (2014). The EU and military operations: a comparative analysis. Abingdon: Routledge.

Gent, S.E. (2008). Going in when it counts: military interventions and the outcome of civil conflicts. International Studies Quarterly 52: 713-35.

Germond, B., and M.E. Smith (2009). Re-thinking European security interests and the ESDP: explaining the EU's anti-piracy operation. Contemporary Security Policy 30/3: 573-93. 
Glaser, C.L. (1993). Why NATO is still best: future security arrangements for Europe. International Security 18, no. 1: 5-50.

Gordon, P.H. (1997-98). Europe's uncommon foreign policy. International Security 22, no. 3: 74-100.

Gowan, R. (2011). From rapid reaction to delayed inaction? Congo, the UN and the EU. International Peacekeeping 18, no. 5: 593-611.

Grevi, G., D. Helly, and D. Keohane (eds.)(2009). European Security and Defence Policy: the first 10 Years. Paris: EU Institute for Security Studies.

Haine, J.Y. (2011). The failure of a European strategic culture - EUFOR Tchad: the last of its kind? Contemporary Security Policy 32: 494-516.

Hoffmann, S. 2000. Towards a common European foreign and security policy? Journal of Common Market Studies 38, no. 2: 189-98.

Huber, D. (2015). A pragmatic actor: the US response to the Arab uprisings. Journal of European Integration 37, no. 1: 57-75.

Juncos, A.E. (2013). EU foreign and security policy in Bosnia: the politics of effectiveness and coherence. Manchester: Manchester University Press.

Kagan, R. 2003. Of paradise and power: America vs. Europe in the new world order. New York: Knopf.

Kempin, Ronja, and Stefan Steinicke (2009). "EUPOL Afghanistan: the credibility-test for Europe's civilian engagement." In M. Asseburg and R. Kempin, (eds.), The EU as a strategic actor in the realm of security and defence? a systematic assessment of ESDP missions and operations. SWP Research Paper 14. Berlin: Stiftung Wissenschaft und Politik.

Korski, D. (2009). EUJUST LEX (Iraq). In G. Grevi, D. Helly, and D. Keohane. 
Kupchan, C.A. (1988). NATO and the Persian Gulf: examining intra-alliance behavior. International Organization 42: 317-346.

Leonard, M. (2006). Why Europe will run the 21st century. London: Public Affairs.

Linklater, A. (2005). A European civilizing process?, in C. Hill and M. Smith (eds.), International relations and the European Union. Oxford: Oxford University Press.

Lucarelli, S. and I. Manners (eds.)(2006). Values and principles in European Union foreign policy. London: Routledge.

Lucarelli, S. and R. Menotti (2006). The use of force as coercive intervention: the conflicting values of the European Union's external action, in S. Lucarelli and I. Manners.

Magone, J.M. (2006). The new world architecture: the role of the European Union in the making of global governance. New Brunswick: Transaction.

Mahncke, D., W. Rees, and W.C. Thompson (2004). Redefining transatlantic security relations: the challenge of change. Manchester: Manchester University Press.

Major, C. and C. Mölling (2013). Towards an EU peacebuilding strategy: the effects of the Lisbon Treaty on the comprehensive approach in the area of civilian crisis management. European Foreign Affairs Review 18, no. 4: 45-62.

Manners, I. (2002). Normative power Europe: a contradiction in terms? Journal of Common Market Studies 40: 234-58.

Manners, I. (2006). Normative power Europe reconsidered: beyond the crossroads. Journal of European Public Policy 13: 182-99. 
March, J.G., and J.P. Olsen (1989). Rediscovering institutions: the organizational basis of politics. New York: Free Press.

McCormick, J. (2006). The European superpower. London: Palgrave Macmillan.

Meyer, C.O. (2005). Convergence towards a European strategic culture? a constructivist framework for explaining changing norms. European Journal of International Relations 11, no. 4: 523-49.

Mounier, G. (2009). Civilian crisis management and the external dimension of JHA: inceptive, functional and institutional similarities. Journal of European Integration 31, no. 1: 45-64.

Noutcheva, G. (2015). Institutional governance of European Neighbourhood Policy in the wake of the Arab Spring. Journal of European Integration 37, no. 1: 1936.

Nuttall, S. (1992). European Political Cooperation. Oxford: Clarendon Press.

Orbie, J. (2006). Civilian power Europe: review of the original and current debates. Cooperation and Conflict 41, no. 1: 123-128.

Pagliari, S. (2013). A wall around Europe? The European regulatory response to the global financial crisis and the turn in transatlantic relations. Journal of European Integration 35, no. 4: 391-408.

Pape, R.A. (2005). Soft balancing against the United States. International Security 30, no. 1: 7-45.

Paul, T.V. (2005). Soft balancing in the age of U.S. primacy. International Security 30, no. 1: 46-71. 
Pond. E. (2003). Friendly fire: the near death of the transatlantic alliance. Washington DC: Brookings.

Posen, B.R. (2006). European Union security and defense policy: A response to unipolarity? Security Studies 15, no. 2: 149-86.

Quille, G. (2004). The European Security Strategy: a framework for EU security interests? International Peacekeeping 11, no. 3: 422-38.

Rayroux, A. (2013). Beyond actorness in EU crisis management: internal functions of external peacekeeping. Journal of European Integration 35, no. 7: 73148.

Regelsberger. E., P. de Schoutheete de Tervarent, and W. Wessels (eds.)(1997). Foreign policy of the European Union: from EPC to CFSP and beyond. Boulder: Lynne Rienner.

Sliwinski, K. (2014). Moving beyond the European Union's weakness as a cyber-security agent. Contemporary Security Policy 35, no. 3: 468-86.

Smith, S. (2013). The European Union and NATO beyond Berlin Plus: the institutionalisation of informal cooperation. $\mathrm{PhD}$ thesis: Loughborough University.

Smith, M.E. (2003). Europe's Foreign and Security Policy: The Institutionalization of Cooperation. Cambridge: Cambridge University Press.

Smith, M.E. (2013). Institutionalizing the 'comprehensive approach' to EU security. European Foreign Affairs Review 18: 25-44.

Smith, M.E. (2017). Europe's Common Security and Defence Policy: Capacity-Building, Experiential Learning, and Institutional Change. Cambridge: Cambridge University Press.

Solana, J. (2003). A secure Europe in a better world: European Security Strategy. Brussels: Council of the European Union. 
Stoddard, E. (2015). Between a rock and a hard place? internal-external legitimacy tensions and EU foreign policy in the European periphery. Journal of European Integration 37, no. 5: 553-70.

Telò, M. (2006). Europe: a civilian power? European Union, global governance, world order. Basingstoke: Palgrave.

Ulriksen, S., C. Gourlay, and C. Mace (2004). Operation Artemis: the shape of things to come? International Peacekeeping 11, no. 3: 508-25.

Walt, S. (1987). The origins of alliances. Ithaca: Cornell University Press.

Walter, B.F. (1997). The critical barrier to civil war settlement. International Organization 51: 335-64.

Whitman, R. (1998). From civilian power to superpower? the international identity of the European Union. London: Palgrave-Macmillan.

Whitman, R. (ed.)(2011). Normative power Europe: empirical and theoretical perspectives. London: Palgrave-Macmillan.

Winn, N., and C. Lord (2001). EU foreign policy beyond the nation-state: joint actions and institutional analysis of the Common Foreign and Security Policy. London: Palgrave-Macmillan.

Youngs, R. (2004). Normative dynamics and strategic interests in the EU's external identity. Journal of Common Market Studies 42: 415-46.

${ }^{1}$ Note that I am not dealing with territorial defence/deterrence issues in this article, as these are covered elsewhere in this special issue (see Howorth).

${ }^{2}$ See the introduction to this special issue.

${ }^{3}$ Such as NATO's 'out of area' initiative to deal with problems in the Persian Gulf; see Kupchan 1988.

${ }^{4}$ That is, humanitarian and rescue tasks, peacekeeping, and tasks of combat forces in crisis management, including peace enforcement. These were defined in 
1992 at the occasion of the WEU Council of Ministers Meeting taking place in Hotel Petersberg (Germany).

${ }^{5}$ Briefly, Berlin Plus allows for 'assured access' to NATO planning capabilities, a 'presumption of availability' to the EU of NATO assets, and NATO European command support for EU-led operations. Berlin Plus discussions began in June 1996 but were not completed (and thus made operational) until 2003.

${ }^{6}$ Also see the follow-up Report on the Implementation of the European Security Strategy: Providing Security in a Changing World (Brussels: Council of the European Union, 2008).

${ }^{7}$ For more detailed discussions of this period of US-EU relations, see Pond 2003; Mahncke, Rees \& Thompson 2004; Quille 2004; Dannreuther \& Peterson 2006.

${ }^{8}$ See for example the EU's Strategy for the External Dimension of Justice and Home Affairs, and the EU Counter-Terrorism Strategy, both adopted in 2005. This EU policy domain is now known as the Area of Freedom, Security, and Justice.

${ }^{9}$ See the European Commission press release on the Defence Union and Permanent Structured Cooperation of 11 December 2017.

${ }^{10}$ See Rayroux 2013 for a more extensive discussion.

${ }^{11}$ On this point see Manners 2002; Youngs 2004; Manners 2006; Telò 2006; and the special issue of the Journal of European Public Policy (Vol. 13, no. 2, 2006) edited by Helene Sjursen on 'What Kind of Power?'

${ }^{12}$ The EU includes four member states - Austria, Finland, Ireland, and Sweden - that still maintain an officially neutral stance towards multilateral defensive alliances, while Denmark has officially opted-out of the defence/military aspects of the CSDP. All of these states, however, have participated in various CSDP actions.

${ }^{13}$ For detailed assessments, see Grevi, Helly \& Keohane 2009; Dijkstra 2010; Gowan 2011; Haine 2011; Juncos 2013; Engberg 2014; Smith 2017.

${ }^{14}$ Although Trump was threatening to withdraw the US from the nuclear agreement with Iran at the time of writing.

${ }^{15}$ Without its own OHQ in Brussels, the EU has to either rely on NATO's OHQ at the Supreme Headquarters Allied Powers Europe (i.e., through Berlin Plus, which requires US approval) or use one of the five EU national OHQs of certain EU member states: the French OHQ in Mont Valérien, Paris; the UK OHQ in Northwood; the German OHQ in Potsdam; the Italian OHQ in Rome; and the Greek OHQ in Larissa. Since the Brexit vote, the EU has taken some small steps to remedy this problem through a new Military Planning and Conduct Capability.

${ }^{16}$ 'Report on the Implementation of the European Security Strategy.'

${ }^{17}$ Eurobarometer surveys consistently show a clear majority of citizens in all

EU member states (including the UK) support the CSDP; the average across the EU is around $75 \%$ in favour. Surveys since the UK Brexit referendum (June 2016) also show a rising majority of Europeans are optimistic about the future of the EU; see the European Commission press release on 'A European spring' of 2 August 2017.

${ }^{18}$ EU Military Staff officials who have worked for both NATO and the EU point out the fact that NATO is not accepted everywhere, and may be seen simply as a tool of the US. For the same reason joint EU-NATO military operations are also controversial for many states, so the EU must continue to develop its own capacities where NATO is unable, unwilling, or unwelcome to operate (Smith 2017).

${ }^{19}$ There is now considerable evidence that the US is not just unwilling but also unable to engage in effective state-building along the lines of what the EU has achieved in Central and Eastern Europe; see Brownlee 2007.

${ }^{20}$ Attributed to US baseball player Vernon Law of the Pittsburgh Pirates. 